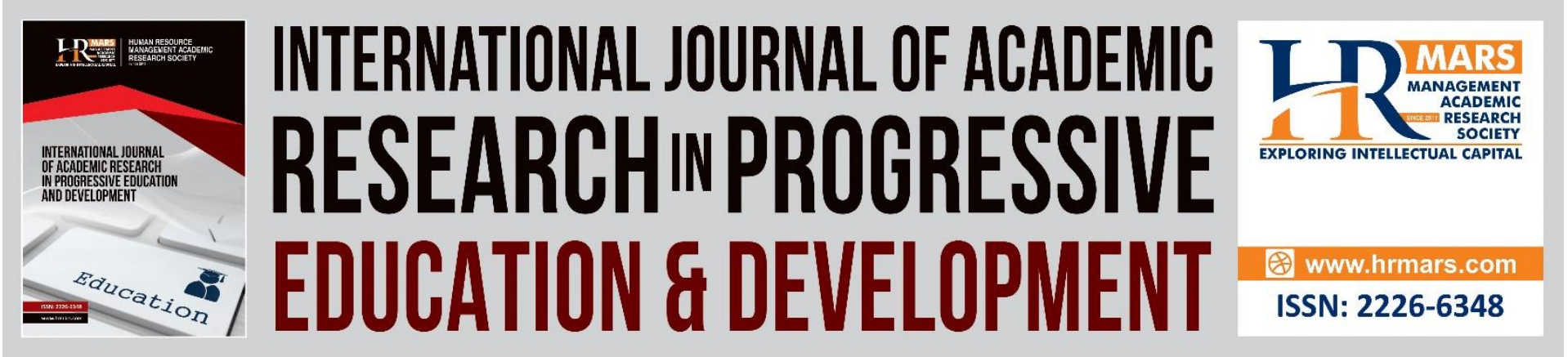

\title{
Acid Attack and its Clinical and Psychological Effect
}

\section{Ahmad Shakib Zalmai, Aimal Amiri}

To Link this Article: http://dx.doi.org/10.6007/IJARPED/v10-i3/10708

DOI:10.6007/IJARPED/v10-i3/10708

Received: 08 June 2021, Revised: 10 July 2021, Accepted: July 2021

Published Online: 20 August 2021

In-Text Citation: (Zalmai \& Amiri, 2021)

To Cite this Article: Zalmai, A. S., \& Amiri, A. (2021). Acid Attack and its Clinical and Psychological Effect. International Journal of Academic Research in Progressive Education and Development, 10(3), 11-19.

Copyright: (c) 2021 The Author(s)

Published by Human Resource Management Academic Research Society (www.hrmars.com)

This article is published under the Creative Commons Attribution (CC BY 4.0) license. Anyone may reproduce, distribute, translate and create derivative works of this article (for both commercial and non-commercial purposes), subject to full attribution to the original publication and authors. The full terms of this license may be seen at: http://creativecommons.org/licences/by/4.0/legalcode

Vol. 10(3) 2021, Pg. 11 - 19

Full Terms \& Conditions of access and use can be found at http://hrmars.com/index.php/pages/detail/publication-ethics 


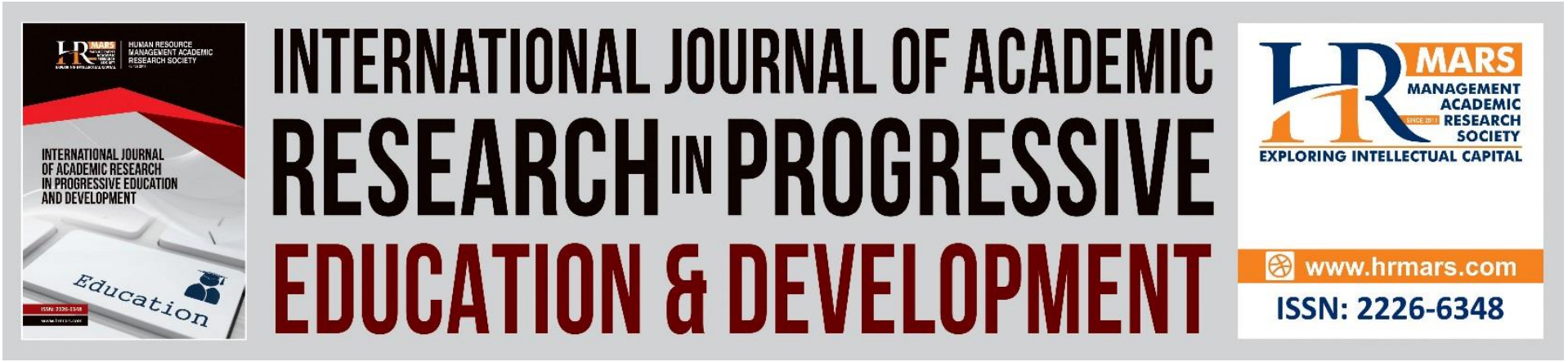

\title{
Acid Attack and its Clinical and Psychological Effect
}

\author{
Ahmad Shakib Zalmai, Aimal Amiri \\ Assistant Professor Forensic Medicine Department, Medical faculty Nangarhar University, \\ Afghanistan \\ Email: shakibzalmai66@gmail.com, aimalhospital1@gmail.com
}

\begin{abstract}
Premeditated throwing of acid on any body part of victim is known as acid attack. It is basically an ominous crime committed truly against women. It can result in number of clinical; Severe pain, permanent disfigurement, subsequent infections and blindness as well as psychological consequences. Current study was conducted to explore the clinical and psychological aspects of acid attack across the globe including Afghanistan. The fundamental aim of the study is to explore the consequences of acid attack which are a serious threat to entire societies and specifically to Afghanistan. The present study also critically overview the literature keeping in view the cases in Afghanistan. The literature provides figures that more than $70 \%$ of acid attacks are due to rejection in love/refusal to marry or for such personal causes.
\end{abstract}

Keywords: Acid Attack, Clinical, Psychological

\section{Introduction}

The Convention on the Elimination of All Forms of Discrimination against Women characterizes sex based savagery as, "viciousness coordinated against women since she is a women or which influences a women lopsidedly." It incorporates physical, mental or sexual misbehave or enduring, dangers of such acts, intimidation and other deprivation of freedom (CEDAW, 1992).

United Nations Organization characterizes violence as, "any demonstration of brutality that outcomes in or is probably going to bring about physical, sexual or mental damage or enduring to an individual including danger of such act lasting or temporary deprivation of freedom whether happening in the general population or private life"(UN, 1993).

According to acid survivor foundation "number of women are facing acid violence which most of the cases go unreported. If one wants to understand the phenomenon of such violence he/she must have sound knowledge of violence against women". Knowledge should be in general and its different forms prevailing in society specifically in Afghanistan (ASF, 2010).

Afghanistan and different other countries where acid violence occurs, campaigners state that brutality is regularly against women, it is just in that nations where there is an Acid Survivors Foundation preparing public help and working with the public authority that move is made" (WHO, 2011). 
Violence is basically the demonstration of causing harm emotionally, physically or in any other way to oneself. Typical demonstration of violence incorporates battling attacks of all levels self-incurred wounds avoidance of other inside companion gathering. Basically acid violence is a phenomena that occurs worldwide and it is just a misconception that attacks are common in subcontinent and most of the committers are Muslim.

Researches provided evidences that different nationalities around the globe commit acid violence and the scenarios are not limited to any religion, location, creed or race (Vaughn, 2011). Acid attack against women is common and a result of historically unequal relations of both genders. Acid attack against women is a manifestation of historically unequal power relations between men and women, which have led to domination over and discrimination against women by men and to the prevention of the full advancement of women. Different researches conducted across the globe have concluded demographics of acid burn victims in those countries. A study done in Guerrero in 2012 reveled that face and neck is the most affected area in $98 \%$ cases. While chest is the next most affected area contributing $43 \%$ of the cases followed by arms (upper limbs) $42 \%$, legs (lower limbs $7.39 \%$ and sex organs $1 \%$ and most of the cases reported in the study was street crimes. In the same way another study carried out in Bangladesh in 2012 sums up the causes of acids attacks as love refusal 66\%, punishment by someone $22 \%$ and competition of business $13 \%$. Again most affected area was face followed by chest and upper limbs of the victim. Coming to the statistics of violence in Afghanistan research shows that numbers of such attacks are increasing day by day but number of register cases is far less than the actual ones. Vicious maltreatment of women is widespread in the country, where according to amnesty international the ministry of women affairs enlisted more than 4000 instances of savagery against women in 2015 and the number is increasing with every passing year (Junejo, 2012).

There is a wide range of clinical (facial disfigurement) and psychological affects (social anxiety, depression, avoidance, stigmatization, shame, discrimination in everyday life, identity threat, unwanted negative attention, loss of confidence, fear to develop new relations, curiosity of people) acid survivors can face in their later life. Hence the current study conducted to critically analyze the clinical and psychological impact of acid attacks on women.

\section{Objectives of the Study}

- To find out the clinical and psychological consequences of acid attacks on women.

- To explore the changes in interpersonal relationships of victim.

\section{Review of Literature}

Acid attack is a global incident that is not restricted to a particular age, caste, religion, gender, or geographical location. Acid attack is a form of gender based violence aimed at silencing and controlling women. This kind of acid attack is used as a weapon against women who refuse sexual or other advances. The use of acid as a weapon began to rise in many developing nations, specifically in South Asia. Since acid can be easily purchased in these countries and is relatively cheap as compared to other weapons like guns, it was a preferred weapon. The first recorded acid attack occurred in India in 1982. Since then, researchers have witnessed an increase in the amount and severity of acid attacks in the region. In many countries acid attacks constitute a hidden form of violence against women and children that often go unreported and the true number of horrific attacks taking place does not come to light (Vaughn, 2011). 
Forensic Medicine and Toxicology: Theory, Oral \& Practical' (2006) by Rabindranath Karmakar, the author mentioned the permanent disfigurement of head and face and permanent loss of eyesight. The book highlights the motive behind this heinous crime. The author also mentions about the treatment or first aid that should be provided to the victim immediately after the attack. 'It was Like Burning in Hell' (2009) by Jane Welsh, the author highlights the motives and causes of acid attack violence in countries like Bangladesh, Pakistan, India and Cambodia. The author highlights the financial difficulties faced by the victim family while undergoing the medical treatment.

Acid Attacks on Women: An Appraisal of the Indian Legal Response' (2011) by Nehaluddin Ahmad, the author in the article highlights the evil practice of acid attack. The intentional throwing or pouring of acid with a motive of defacing or killing a person is used as a brutal way of taking revenge. The author wants to highlight the physical as well as psychological consequences of such attack, the author also covers the insufficiency of the law to give justice to the victims and the possible steps that can be taken to strengthen the law to deal with such attacks. Vitriolage \& India- the Modern Weapon of Revenge' (2013) by Parvathi Menon and Sanjay Vashistha, the author in the article highlights the common reasons of acid violence and the post attack evil consequences that the victims and their families undergo. Two of the most important issues raised by the authors in this article are 'role of police in the investigation of acid attacks' and 'judiciary's role in prosecuting the perpetrators of acid attack'.

A Fate Worse than Death: A Critical Exploration of Acid Attack Violence in India' (2015) by Aishwarya Deb and Prithwish Roy Chowdhury, the author in the article considers 'social stigmatization' and 'leniency of laws in punishing perpetrators' as a major reason of why many such violent incidents go unreported. Looking at the gender dimension of such attacks the authors narrates that most of the reported acid attacks have been committed on women as a weapon of dominating them by showing masculinity and superiority.

\section{Reasons for Acid Attack}

Studies have revealed that that most of the time acid attack related with women and young girl and the observable reason being is the rejection of marriage and love or refusal by woman of sexual advances and dowry disagreements. The other noted reason for such attack could be land, property and any kind of business disputes. Campaign and Struggle Against Acid Attacks on Women (CSAAAW) documented that sexual harassment or assault in response to a woman or girl refusing such advances or demanding that the violence stop often precede such attacks." As per the Law Commission of India in its 226th report has asserted that the majority of acid attack victims are women, particularly young women for spurning suitors, for rejecting proposals of marriage, for denying dowry etc. The attacker cannot bear the fact that he has been rejected and seeks to destroy the body of the woman who has dared to stand up to him."

This is the way of our society's outlook on the women. Women still cannot combat for their rights which are the basic human right of every individual. Women are still regarded as "possession", and a man is sole decision maker as per our modern society is concerned and when a woman refuses a man, it is seen as destroying his reputation, prestige and honor, and he restores it by burning her face with acids. Men throw acid on women as a mark of their virility and supremacy. By impairing her face, man derives a perverted pleasure and his male ego gets pleased. Another major reason may be dowry problems or other marital problems. Though taking of dowry is a punishable offence, still it is most pervasive in many areas. It is 
considered as the responsibility of the bride's family and has to experience a huge social disgrace if not complied with. In India, many women claim that they are the strike by acid due to the failure to meet the financial expectations of their in-laws. In addition to this, land and property disputes may also be said to be the key reasons for the commission of this brutal offence. The study of newspaper reports in India evinces that nearly $40 \%$ of the attacks materialized between unrelated people, due to the business rivalry, sales disputes, land disputes or revenge between families. Thus, from the above discussion one can reach the conclusion that men resort to acid attacks as a means to intimidate women and to impose their authority on her. Such kind of heinous attacks boost his male ego and make him feel that he is the proud inventor of God and has created the patriarchal society. Females between 11 and 30 years are the most susceptible to such attacks, in $36 \%$ of the incidents the victims are targeted for rejection of marriage proposals. Therefore, the main cause that is seen to be behind the acid attack is the rejection of sexual advances.

\section{Methodology}

Secondary instrument were used in order to accomplish the research objectives. Different necessary domains of interpersonal relationships and psychology were covered in the guidelines.

\section{Procedure}

The current study was conducted to explore the clinical and psychological aspects of acid attack and examine the consequences of acid attack which are a serious threat to entire societies and specifically to Afghanistan. Therefore, this research emphasizes and collect data from previous studies carried out in the same domain across the globe. In addition, different reports issued by various national international organizations regarding clinical and psychological aspects of acid attacks critically reviewed to explore the causes of acid attacks and its clinical and psychological impact. Therefore, the present research was carried out by deploying formation of interview guideline. Hence exiting literature was reviewed as well as subject specialists reports from home and abroad are reviewed. In addition, reports from doctors, and burn center heads were contacted to get a clear picture of the actual condition and situation of acid burn victims across the globe an in Afghanistan.

\section{Analysis}

Thematic analysis has been used to construct emergent themes from the obtained data.

\section{Results}

From the analytical reports and literature, ten cluster themes arranged into three emergent themes were obtained.

\section{Clinical and Psychological Effects}

1) Facial disfigurement and related body image. Facial disfigurement is the most evident effect of acid attack. Victimization put a disastrous change in the image of body and physical appearance as one of the victims from sample describe this change in her own words "I was beautiful and I can never be that beautiful again". 
2) Psychological distress. Throw back of what happened to you always haunt your mind. It is clear from the result that psychological distress is another unavoidable consequence of acid attack. It can be at personal (insecurity about her personal wellbeing and carrier), family (collateral damage to the mental health of victim and her family) and societal level (to face harsh behavior of society). Such distress can lead to suicidal attempts. As one the respondents said "even I had thought of suicide when I realize that I can never be the same again.

3) Depression. Depression is another common psychological effect of such attacks. Such victimization can lead the victims towards deep sorrow and depressed feelings. One of the responded said "my whole days and nights were full of weeping and crying with various levels of anxiety". This phrase is a depiction of victim's depression and anxiety level.

4) Sense of identity loss. Results indicate that most of the women who face such victimization can't face people for long time just because of the feeling of loss of actual identity. In her opinion her disfigurement fades her identity away. A loss of personal recognition presumed as inner wound which grows with passage of time and in struggle to fight this in recognition respondents try to escape from personal interactions as it is evident from the words "I try to escape from the people who visit home by locking myself in the room".

Results indicate that repeated attacks of insecurity, emotional breakdown, anger, social breakup, anxious behavior, suicidal attempts, and rebellion attitude are few others of the many psychological effects of acid attacks.

\section{Interpersonal Relationships}

1) Acid attacks and family relation. Results of the study indicated that there exists both optimistic and pessimistic change in the relationships with very close family. In every case victim witnessed a positive support and at the same time counter negative behavior by family members.

2) Acid attack and extended family. Again both support and suspicion of extended family impacts in positive and negative way respectively. According to respondents "suspicion of extended family is the worst part of victimization and their support is the actual peace in such a distressed condition".

3) Acid attack and friends. Most of the time contrary to family members and close relations friends play a vital role in rehabilitation of the victim's physical and emotional wellbeing as they proof themselves the most trusty and supportive in the whole process.

\section{Strategies to deal with the Consequences of Acid Attacks}

The literature and reports suggested that three different types of strategies are helpful in coping with the consequences of acid attacks. 


\section{1) Religious strategy}

Results of the study indicate that Essence of any recovery and rehabilitation lies within the strong spiritual support and the religion provide it at most. Different rituals, prayers and recitations are the prominent form of religious coping methods.

\section{2) Problem focused strategy}

Study indicate that problem focused strategy is also helpful in copping the consequences of such attacks. Every victim faced a numerous number of problems and try to solve it in her own way for example: one individual try to find job for herself to end the depression caused by lowliness at the same time other one try to locate herself in a nearby beauty parlor.

\section{3) Emotion focused Strategy}

Research indicates that the most important emotional strategy are: Sharing, Avoidance and distancing. Sharing with mother is very critical as it's the most loving and unconditional supportive relation. Avoidance from the fake friends and colleagues who reminds the attack incidence. Distancing from any kind of anxiety and stress proves helpful in attaining calmness and stability.

\section{Conclusion}

This research is based on existing literature emphasized on the interpersonal relationships, psychological effects, and coping strategies of acid burn female victims. The literature provides figures that more than $70 \%$ of acid attacks are due to rejection in love/refusal to marry or for such personal causes. This analytical literature documents and support family and friends, in any form, appeared as a positive indicator whereas; staring and inappropriate comments from general public appeared as negative indicators of psychosocial adjustment for these victims. Changes in body image, experience of depression and PTSD symptoms were evident in all the victims and they tend to use avoidant coping at earlier stages of their victimization. A shift to focused problem solving was undertaken by many of the respondents at later stages of their victimization in which they had undergone a number of surgeries and regained some of their facial features.

\section{References}

Achenbach, T. M., \& Rescorla, L. A. (2000). Manual for the ASEBA Preschool Forms \& Profiles. Burlington, VT: University of Vermont, Department of Psychiatry.

Achenbach, T. M., \& Rescorla, L. A. (1991). Manual for Child Behavior Checklist/4-18 and 1991 Profile. Burlington, VT: University of Vermont, Department of Psychiatry.

American Psychiatric Association (1994). Diagnostic and Statistical Manual of Mental Disorders ( $4^{\text {th }}$ Ed.). Washington, DC: American Psychiatric Association.

Anthony, J. C., \& Helzer, J. E. (1991). Syndromes of drug abuse and dependence (pg. 116-154). In Robins, L.N. \& Regier, D.A. (Eds.) Psychiatric Disorders in America: The Epidemiologic Catchment Area Study. The Free Press. New York.

Basile, K. C. (2002). Prevalence of wife rape and other intimate partner sexual coercion in a nationally representative sample of women. Violence and Victims. 17(5):511-524. 
DEVELOPMENT

Vol. 10, No. 3, 2021, E-ISSN: 2226-6348 @ 2021 HRMARS

Bennice, J. A., Resick, P. A. (2003). Marital rape. History, Research, and Practice. Trauma, Violence, \& Abuse. 4(3):228-246.

Bennice, J. A., Resick, P. A., Mechanic, M., Astin, M. (2003). The relative effects of intimate partner physical and sexual violence on post-traumatic stress disorder symptomatology. Violence and Victims, 18(1):87-94.

Bergen, R. K. (1996). Wife rape: Understanding the responses of survivors and service providers. Thousand Oaks, CA: Sage Publications.

Breslau, N., Peterson, E. L., Kessler, R. C., \& Schultz, L. R. (1999). Short screening scale for DSM-IV Posttraumatic stress disorder. American Journal of Psychiatry. 156:908-911.

Browne, A. (1993). Violence against women by male partners: Prevalence, outcomes, and policy implications. American Psychologis.t 48:1077-1087.

Campbell, J. (1986). Assessment of risk of homicide for battered women. Advances of Nursing Science. 8:36-51.

Campbell, J. (1989). Women's responses to sexual abuse in intimate relationships. Health care for women international. 10:335-346.

Campbell, J. C., \& Alford, P. (1989). The dark consequences of marital rape. American Journal of Nursing. 89:946-949.

Campbell, J. (1995). Assessing Dangerousness: Violence by Sexual Offenders, Batterers, and Child Abusers. Thousand Oaks, CA: Sage Publications.

Campbell, J. C., \& Soeken, K. (1999). Forced sex and Intimate Partner Violence: Effects on Women's Risk and Women's Health. Violence against women. 51(9);1017-1035.

Campbell, J. C., \& Soeken, K. (1999b). Women's responses to battering over time: Analysis of change. Journal of Interpersonal Violence. 14:21-40.

Campbell, J. C., Webster, D., Koziol-McLain, J., Block, C., Campbell, D., Curry, M., Gary, F., McFarlane, J., Sachs, C., Sharps, P., Ulrich, Y., Wilt, S., Manganello, J., Xu, X., Schollenberger, J., \& Frye, V. (2003). Risk factors for femicide in abusive relationships: Results from a multi-site case control study. American Journal of Public Health. 93(7):1089-1097.

Campbell, R., Sullivan, C.M., \& Davisdon, W.S. (1995). Depression in women who use domestic violence shelters: Changes in depression over time. Psychology of Women Quarterly. 19:237-255.

Coker, A. L., Smith, P. S., Betha, L., King, M. R., \& McKeown, R. E. (2000). Physical health consequences of physical and psychological intimate partner violence. Archives of Family Medicine. 9:451-457.

Coker, A. L., Smith, P. S., Thompson, M. P., McKeown, R. E., Bethea, L., \& Davis, K. E. (2002). Social support protects against the Negative Effects of Partner Violence on Mental Health. Journal of Women's Health \& Gender-Based Medicine. 11(5):465-476.

Curry, M. A. (1998). The interrelationship between abuse, substance use and psychosocial stress during pregnancy. Journal of Obstetric, Gynecologic, and Neonatal Nursing, 27:692-699.

Davila, Y. R., \& Brackley, M. H. (1999). Mexican and Mexican American women in a battered women's shelter: Barriers to condom negotiation for HIV/AIDS prevention. Issues in Mental Health Nursing, 20, 333-355.

Derogatis, L. R. (2001). Brief Symptom Inventory - 18. Administration, scoring and procedure manual. Minneapolis, MN: NCS Pearson, Inc. 
Ehrensaft, M. K., Cohen, P., Brown, J., Smailes, E., Chen, H., \& Johnson, J. G. (2003). Intergenerational transmission of partner violence: A 20-year prospective study. Journal of consulting and clinical psychology. 71(4):741-753.

Evins, G., \& Chescheir, N. (1996). Prevalence of domestic violence among women seeking abortion services. Women's Health Issues, 6(4):203-210.

Ullah, M. (2020). Women Empowerment and Social Development in Afghanistan through Micro Finance. International Journal of Academic Research in Business and Social Sciences, 10(12), 377-389. 